\title{
Dynamics and determinants of export diversification in Brazil from 2003 to 2013 *
}

\author{
Heder Carlos de Oliveira ${ }^{* *}$ \\ Elodie Jegu ${ }^{* * *}$ \\ Venussia Eliane Santos ${ }^{* * * *}$
}

\begin{abstract}
Brazil was successful in diversifying its export package from the 1960s to the beginning of the twenty-first century. However, this performance has been more ambiguous over the last decade. This study explores the literature on the impact of export diversification on economic growth and the determinants of successful diversification. More specifically, it analyzes the dynamics of Brazilian export diversification between 2003 and 2013. The results suggest that, overall, exports momentarily concentrated in 2004, 2008 and 2012, but rejoiced from a diversification spike in 2005. Southern and Southeastern states are found to have more diversified exports, but Central-West and Northeastern states have experienced higher diversification rates since 2006. Via a dynamic panel data analysis, using System General Methods of Moments estimation method, including all Brazilian states, past diversification performances, education, patents per capita, credits and public investments are found to be significant determinants of Brazilian export diversification.
\end{abstract}

Keywords: Economic growth; Diversification; Dynamic Panel Data; Brazil.

\section{Resumo}

Dinâmica e determinantes da diversificação das exportações brasileiras no período de 2003 a 2013

Durante o período de 1960 até o início do século XXI, o Brasil apresentou um processo de diversificação das exportações do país de forma satisfatória. No entanto, essa performance tem sido bastante ambígua no decorrer das últimas décadas. Esse artigo, além de explorar a literatura que trata da relação entre diversificação das exportações e crescimento econômico, analisa os determinantes da diversificação das exportações brasileiras no período de 2003 a 2013. Para atingir os objetivos do artigo, foi utilizada a metodologia de Painel Dinâmico para os estados brasileiros. Os resultados indicam que, em geral, as exportações brasileiras concentraram-se momentaneamente nos anos de 2004, 2008 e 2012, mas tiveram um ligeiro processo de diversificação no ano 2005. Os estados do Sul e Sudeste são aqueles que apresentam maior diversificação dos produtos exportados, mas os estados do Centro-Oeste e Nordeste experimentam, desde o ano de 2006, altas taxas de diversificação das suas pautas de exportação. Além disso, os resultados econométricos indicam que as variáveis de educação, patentes per capitas, acesso ao crédito e investimentos públicos, demonstraram relação positiva e significativa com o processo de diversificação da economia brasileira no período estudado.

Palavras-chave: Crescimento econômico; Diversificação; Dados em painel dinâmico; Brasil.

JEL C33, O14, O54.

${ }^{*}$ Article received on December 7, 2017 and approved on May 6, 2018.

${ }^{* *}$ Assistant Professor at the Department of Economics at The Federal University of Ouro Preto (UFOP), Ouro Preto, MG, Brazil. E-mail: heder.oliveira@ ufop.edu.br.

**** Professor - Utrecht School of Economics, Utrecht University, Utrecht, the Netherlands. E-mail: e.jegu@gmail.com.

${ }^{* * * * *}$ Economist at INPI - National Institute of Industrial Property, Brasília, DF, Brazil. E-mail: venussia@gmail.com. 


\section{Introduction}

The end of the twentieth century witnessed the economic growth prowess of numerous developing and mid-income countries (DMCs), notably the BRICS countries: Brazil, Russia, India, China and South Africa. During this period, fueled by large natural resource endowments, cheap labor supply, and more lenient industrial policies, many DMCs upon trade liberalization developed concentrated commodity-based production and export bundles (Felipe, 2015). Collier and Dollar (2002) suggest that as they specialized, these countries were able to take advantage of growing global demand for commodities and the commodity price boom, all whilst relying on their comparative advantage in the production of labor-intensive products.

The growth experienced by DMCs is based on traditional economic and trade theory. Since Adam Smith, specialization has in fact been promoted by economic literature as being a strategy to boost domestic, and worldwide economic growth (Mejía, 2011). Some of the benefits of specialization include the fact that it allows for economies of scales, that it reduces opportunity costs by enabling countries to focus on the production and exports of goods in which they have a comparative advantage, and that it is the natural result of market forces, and thus generates the most efficient resource allocation (Kaulich, 2012).

There are, however, reasons to believe that similar growth exploits by DMCs will be more difficult to reproduce and sustain in the twenty-first century. Felipe (2015) states that attaining a 'high-income status' via mainly relying on the exploitation and exportation of primary goods, and overall 'basic' products, will become challenging. Exports concentrated around commodities have been argued to suffer from low terms of trade (Toye; Toye, 2003), to be more recurrently subject to volatilities, and to have low potential to foster the accumulation of physical and human capabilities necessary for technical change and the production of more complex goods (Gylfason; Herbertsson; Zoega, 1999). Moreover, Lall (2000) points out that the continuous development of labor-saving technologies, and the increasing importance of exports' quality, flexibility and design in securing international trade competitiveness, have reduced the benefits of having a large and cheap low-skilled labor force.

In addition to the challenges imposed by these changes, recent economic literature, such as Perman et al. (2011) and Lucas (1988), affirms that countries that based their economic growth on specialized production and exports, especially in low-skill intensive goods, enjoyed improved economic performance. However, they reached no real convergence opportunity nor an effective means to achieve sustained economic growth. In response to this, recent economic literature has demonstrated that diversifying exports is a more effective strategy for DMCs to secure stable and successful economic growth, with more convergence potential (e.g. Kalich, 2012). One of the main reasons for this is that export diversification decreases exports volatility and provides more dynamic benefits to the economic environment (Agosin, 2007).

Brazil experienced one of the highest worldwide economic growths in the last three decades, making it the 6th largest economy (Inman, 2012). While the Brazilian economy 
benefited greatly from the boom in commodity prices (Collier and Dollar, 2002), Brazil has also been prized for having extensively diversified the structure of its exports, which, in the 1960s, was mainly composed of commodities. In more recent years, however, the Brazilian economy has faced difficulties. Growth in GDP in Brazil has declined considerably (Verheij; Oliveira, 2017). In parallel to this, the evolution of Brazilian export diversification throughout the last decade has been ambiguous. Arnold et al. (2015), for example, emphasize that since the 1980s, the Brazilian industrial sector has decreased in size considerably, especially relative to that of competing East Asian and LAC economies. Cirera, Martin and Markwald (2012) also point out that throughout the last decade, Brazilian exports of primary goods have become more concentrated. On the other hand, the authors also find that Brazil has introduced more complex goods to its export bundle. A detailed evaluation of the dynamics of Brazilian export diversification could provide more clarity on this matter.

The two following questions will thus guide the present study. First, how did Brazilian exports' diversification evolve between 2003 and 2013 at the national and regional levels? Secondly, what were some of the determinant factors of the observed diversification pattern in Brazil between 2003 and 2013?

The paper is structured as follows. The Theoretical Framework provides an overview of the arguments supporting specialization, of those exploring the relationship between diversification and economic growth, and of the literature on successful diversification. This is followed by a preview analysis of the evolution of the Brazilian export structure. The empirical case study utilizes the Industry Diversity Index developed by Haussmann to analyze the evolution of Brazilian exports' diversification across Brazilian states from 2003 to 2013. The empirical case study also researches the determinant factors of diversification during that period. Panel data under a System General Method of Movements is utilized to carry out the study. Finally, a brief general conclusion that summarizes the findings of the entire research is presented.

\section{Theoretical framework}

\subsection{Specialization}

The Ricardian theory is one of the earliest pillars of the literature to support export specialization (Kaulich, 2012). Based on this model, each country has a comparative advantage in the production of goods they are the most efficient at producing. Literature on specialization has argued that by specializing in the exportation of such goods, countries are able to base their economic growth on goods which are subject to lower opportunity costs. This, ultimately, is expected to result in overall increases in output, making all involved countries better off, and specialization beneficial across the board.

The other two pioneers of classical trade theory, Heckscher and Ohlin (HO), made two central contributions to this strand of literature. Firstly, countries have different endowments of production factors. Secondly, given that the production of different products requires 
different production factors, their model suggests that in the context of free trade, countries naturally specialize in producing and exporting goods and services in which they have a comparative advantage (Perman et al., 2011). As pointed out by Hausman, Hwang and Rodrik (2005), a country's production mix thus tends to be regarded by this strand of literature as dictated by its given endowments of 'fundamental' production factors: physical capital, human capital, labor, natural resources and quality of institutions. Moreover, they further note that attempting to change one's production mix beyond the production frontier resulting from given endowment bundles is also expected to be obstructive to economic growth.

Specialization is also portrayed by supporters of traditional trade theory as being the 'natural' result of free-market forces (Felipe, 2015). As discussed by Husted and Melvin (2010), in the absence of market failures, specialization is expected to generate the most efficient resource allocations, which should lead to substantial economic growth and welfare improvements. Based on the $\mathrm{HO}$ model, the $\mathrm{HO}$ theorem of factor price equalization further suggests that in the context of free trade, specialization should lead to the equalization of international factor prices. This idea has been supported by Krugman (1987), who further argues that specialized production and exports similarly foster economic growth regardless of which product they focus on.

Finally, specialization has been argued to generate economic growth via more dynamic effects on economic development. It is for instance commonly argued to foster intra-sectorial productivity as it facilitates both economies of scale and agglomeration economies (Collier; Dollar, 2002). Romer (1990) emphasizes that the accumulation of capabilities, notably human capital, in a given sector generates learning-by-doing, fosters technical change, productivity and intra-sectorial growth. The mechanism is straightforward: gaining experience in performing the same activity increases one's performance in that given activity.

More recent economic literature has nonetheless increasingly questioned the benefits of specialization for DMCs economic growth. Lucas (1988), for example, points out that the accumulation of human and technological skills within the same sector leads to learning-bydoing, but in such a way that only reinforces countries' capacity to produce specific goods and the comparative advantage they already have in that one good. Thus, countries can enjoy some economic and productivity growth, but to a limited extent. Indeed, as suggested by Perman et al. (2011), observing countries' economic performance worldwide also shows that the economic convergence expected by the specialization literature, has yet to be fully observed. While some developing countries have enjoyed tremendous economic growth, others have lagged behind and are currently suffering from the crash of commodity prices (Mariscal; Powell, 2014; Arnold et al., 2015). Moreover, even those that rejoiced from considerable economic growth, such as Brazil, are still viewed as mid-income countries, that have faced a slow-down in their economic growth.

\subsection{Diversification}

The literature on diversification suggests that, compared to specializing, higher and more stable economic growth can be achieved if countries diversify their export bundles. 
Overall, export diversification has been both theoretically and empirically shown to be a catalyst for economic growth. The importance of diversification for economic development has been promoted by many economists, including Kuznets (1971) and Grossman and Helpman (1992).

As pointed out by Chandra, Boccardo and Osorio (2007), for example, empirical evidence of this correlation even holds after accounting for a range of micro and macro contextual factors, such as initial GDP per capita, governance, macro-economic environment, and investment in human capital. Evidence is also found when utilizing different measures of diversification, and for different levels of analysis - global, regional and national levels.

Al-Marhubi (2000) and Aditya and Acharyya (2013) find that export diversification is associated with a considerably faster average annual growth rate of real GDP per capita. They also report that the impact of diversifications on growth is especially large when a country's total exports are higher than the world average level of exports. These findings are of relevance to Brazil. The World Trade Organization (2015) indeed reports that as of 2014, Brazil was the $25^{\text {th }}$ leading exporting country in world merchandise trade, the second-largest exporter in world merchandise trade amongst LACs, and the largest in South America. Additionally, Agosin (2007) suggests that $80 \%$ of the variation in economic growth rate between LAC and Asian countries, between 1980 and 2002, was explained by diversification, rule of law and investment performances.

A greater understanding of the channels through which export diversification fosters economic growth leads to further insights into the array of potential benefits to the Brazilian economy. Overall, economic literature tends to highlight two main mechanisms throughout which diversification promotes long-term economic growth and higher convergence possibilities: decreased export volatility and its capacity to promote dynamic growth.

\subsubsection{Diversification and volatility}

The capacity of diversification to stabilize exports and countries' overall economic performances has been supported empirically and theoretically. Mobarak (2005) for instance, using a data set of 80 countries, finds a significant negative correlation between diversification and volatility. The main argument is that, by diversifying, countries decrease their reliance on few economic sources, and thus become less vulnerable to downturns in one or few exporting sectors and to subsequent volatile export earnings (Herzer; Felicitas Nowak-Lehnmann, 2006).

Moreover, Ramey and Ramey (1995) presented empirical evidence showing that countries with higher economic volatility experience slower economic growth. These authors suggest that development results from long-term sustained economic growth, rather than from successive economic booms and busts.

There are different explanations for the volatility of a negative impact on both shortterm and long-term economic development. First, as emphasized by Agosin (2007), moments 
of economic contraction resulting from volatile economic performances can directly deteriorate both accumulated physical and human capital. One can easily imagine that workers who are laid off and out of professional practice for a certain period of time run the risk of being less productive upon returning to their positions.

Secondly, as highlighted by the literature on taxation, a volatile economy leads to volatile public revenues, and limited investment capacity. As Alink and Kommer (2011) suggest, this is problematic given that public revenues enable continuous and sought out maintenance and investments in infrastructure, education and overall social welfare, which are crucial to economic progress.

Thirdly, volatilities also discourage investments. Dawe (1996) argues that while uncertainty arising from export volatility could actually increase short-term investments, they cause a decrease in quality investments and long-run investment decisions even when capital markets are perfect. In addition, if export volatilities lead to unstable incomes in a key sector of the economy, demand and prices in other sectors will also fluctuate, potentially causing inefficiencies across the board.

Diversification's capacity to smooth export volatilities is especially important to DMCs. According to Loayza et al. (2007), compared to more established economies, DMCs have both more difficulties coping with the consequences of export volatilities, and they are more likely to suffer from them on a recurrent basis. First, DMCs tend to have less effective 'shock absorbers', namely financial markets able to diversify macroeconomic risks, and "stabilization policies to counter aggregate shocks" (Loayza et al., 2007). Yet, they also have a higher need to maintain a performing economy to be able to keep investing in infrastructure and human capital.

Secondly, DMCs' exports tend to be more often subject to both internal and external shocks. One can envision that if DMCs rely on less effective governmental agencies, industrial managements, infrastructures and physical capital, as well as less prepared human capital, they are likely to be more vulnerable to internal shocks such as those previously listed (Loayza et al., 2007). In addition, goods commonly exported by DMCs, notably primary goods such as agricultural products and oil present more volatile prices and highly seasonal. This appears to be especially relevant to Brazil given that commodity exports make up an important share of its total export bundle (Cirera, martin and Markwald, 2012).

\subsubsection{Diversification and dynamic benefits}

Successful diversification also provides different "dynamic benefits" (Agosin, 2007). Four of these dynamic benefits will be briefly discussed, namely the potential for diversification to promote cost discovery, demand discovery, intra-industry endogenous growth, and inter-sectoral growth. 
Diversification's capacity to foster cost discoveries has been extensively discussed by Hausmann and Rodrick (2003). They explain that as countries diversify, they can discover new areas of comparative advantage. Ultimately, as a result of this exploration process, they can then select a more efficient production-mix that increases their economic growth.

A second similar dynamic benefit fostered by diversification, foreign demand discoveries, is discussed by Vettas (2000). As pointed out by the author, foreign customers are not aware of all the products produced abroad. However, as they are exposed to new goods, their knowledge of these goods increases, and so does their knowledge of the quality of the exporting country's products overall. Demand discoveries can thus lead to a virtuous circle, promoting further demand discoveries.

Gnangnon and Moser (2014), for instance, note that diversifying exports can result in fast intra-sectorial growth because of exporters' increased exposition to competition, and the necessity to comply with foreign standards fosters productivity growth. Moreover, Herzer and Felicitas Nowak-Lehnmann (2006) state that different foreign buyers themselves also tend to transfer an array of know-how to domestic exporters, such as how to improve overall marketing practices and production processes, which creates an ongoing, learning process.

Finally, Al-Marhubi (2000) argues that export diversification fosters long-term economic development by increasing inter-sectoral growth. He notes that as countries engage in the production of diversified products, they ultimately require, motivate and generate a wider variety of production inputs, learning-by-doing and capabilities, including diversified skills, production techniques and technologies. These can in turn be applied to other sectors, and even utilized as complementary to one another.

\subsubsection{Determinants of diversification}

As can be seen, recent literature has pointed out the benefits that diversifying exports can have on economic growth. Chandra, Boccardo and Osorio (2007), however, have observed that throughout the last couple of decades, there has been a large variation in the extent to which DMCs have been able to successfully diversify. Thus far, the literature on successful diversification has mainly focused on two aspects. The first strand concentrates on evaluating the economic growth and diversification potential of different diversification scopes. The second strand of literature more specifically focuses on identifying country-specific determinants of export diversification.

Regarding diversification scope, the composition of export bundles has been demonstrated to influence both economic growth and future diversification potential. Chandra, Boccardo and Osorio (2007) point out that for some time the standard view has been that extending exports towards manufacturing and service industries, away from the primary goods industries, reflects and fosters more successful diversification. Breton et al. (2009) affirm that services include a wide array of export opportunities that are important diversification and 
growth channels for DMCs. As they point out, not only do services require the development of varied skills, they are also in themselves key inputs in the production of various goods.

Product-based diversification, specifically diversification towards manufactured goods, tends to be have a higher potential for economic growth and future diversification. Gylfason, Herbertsson, and Zoega, (1999) and Herzer and Felicitas (2006) for example suggest that manufacturing sectors tend to be associated with a higher intra-sectorial potential for technological progress and the development of a highly-skilled labor force, notably because of the fact that their production requires higher technological capacity and skilled-labor. In addition, the same authors point out that secondary goods are commonly argued to foster future diversification since they generate more inter-sectoral spillovers.

On the other hand, Sachs and Warner (2001) and Gylfason, Herbertsson, and Zoega (1999) argue that focusing exports on primary goods can crowd-out growth-leading activities, and obstruct the development of competitiveness in other more productive exports that heavily rely on high-skilled labor and high-tech physical capital, particularly the manufacturing sector. This is because, overall, the production of primary goods is argued to have a low potential for technological development, and growth-leading intersectional physical and human capital spillovers (Chandra, Boccardo and Osorio, 2007). Moreover, commodities are doomed to face declining terms of trade and are also associated with higher export volatility (Toye; Toye, 2003).

Some recent studies have nonetheless challenged the argument that commodity exports necessarily slow down or hinder diversification and growth processes. Lederman and Malhoney (2012) find that overall commodities offer less potential for vertical diversification, but that this does not extend to all commodity-based exports. Coffee and wine for instance are two examples of commodities that harbor a sophistication variance in their final products similar to that of aircrafts. Gelb (2010) further suggests that a variety of commodity-based sectors are just as prone to fostering technical change, learning-by-doing opportunities, production linkages, and inter-sectoral spillovers as manufacturing sectors. The transformation of primary goods can also result in the making of new, more industrialized products. Consequently, primary goods can serve as a trampoline towards increasingly manufactured export bundles (Herzer; Felicitas, 2006).

The observations made could be especially relevant in the case of Brazil, given that studies such as Newfarmer, Walkenhorst, and Shaw (2009) suggest that what often blocks DMCs from securing sustained exports diversification, and diversification-lead economic growth, is the high 'death rate' of new exports. As a result, they state that "attention to sustaining and growing viable products - through improvements in quality and progressive reductions in costs associated with economies of scale and increases in productivity - can have a high payoff."

Gelb (2010) notes that what hinders technological progress and export diversification are not necessarily primary goods exports in themselves, but rather, a conscious over-reliance 
on those exports, and low endowments in 'complementary' capital, namely governance, institutional and human capital. On the contrary, he states that, when handled properly, earnings from commodity exports can be used to finance the accumulation of capabilities and inputs necessary to the development of other sectors. Overall, commodities could thus have similar potential to foster export diversification and economic growth.

Last but not least, different studies have indeed found that some country-specific factors are key determinants of countries' capacity to produce different qualities and types of goods (Lederman and Maloney, 2012). In addition to this, Hausman, and Rodrik (2003) suggest that the failure of a country to diversify is a result of market failure, namely that laissez-faire policies result in the under-provision of entrepreneurship and investments required to generate innovations and lead to an over-accumulation of unproductive firms. More broadly, Elhiraika and Mbate (2014) state that some of the factors recurrently found to be significant determinants of export diversification "include per capita income, investment, human capital, population, terms of trade, exchange rate, geographical location and institutional and governance factors."

\section{Evolution of Brazilian export diversification from 1962 to 2015}

Starting with a general overview of Brazilian diversification, it is worth noting that different studies highlight Brazil as an example of a country that has been able to diversify a highly concentrated export basket. Rivera-Batiz and Olivia (2003) suggest that Brazilian export diversification by the end of the twentieth century was the most successful amongst Latin American countries. Different empirical studies also hint at Brazil's performance before the twenty-first century. Debczy and Berrettoni (2006) and Mejia (2011) illustrate the evolution of Brazilian export diversification in contrast to that of other Latin American economies, from 1962 to 2002 based on the Herfindahl-Hirschman Index (HHI). Both studies suggest that during this period, Brazilian exports grew considerably more diversified. Figure 1 shows the evolution of Brazilian diversification at the national level from 2002 to 2014.

Figure 1

Evolution of total Brazilian export diversification

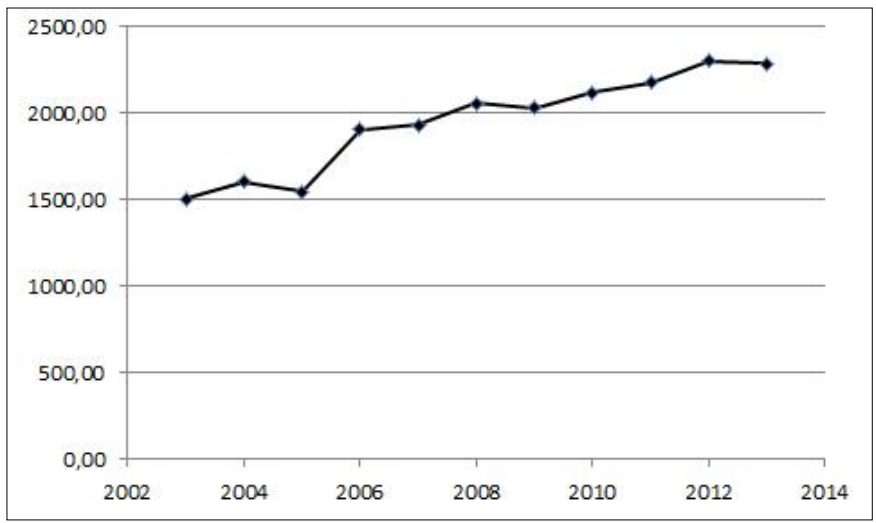

Source: Author's elaboration based on Fapemig (2016). 
In general, throughout the entire period, the average level of export diversification in Brazil increased by approximately 50 units in the Industry Diversity Index ${ }^{1}$. Almost half of this increase was achieved during the 2005 diversification spike. In fact, throughout that single year, Brazilian exports diversified more than they did in the eight years that followed. In contrast, diversification levels stagnated before that period, and increased at a relatively slow rate thereon after.

Figure 2 allows for a closer look at the evolution of Brazilian export diversification at the regional level. First, it shows that there is a considerable variation in the extent to which different Brazilian regions have diversified their exports. There is a large diversification gap between regions located more in the South, and those located more in the North of the country. On average, Southeastern states, closely followed by Southern states, have indeed boasted the most diversified exports throughout the entire analyzed period. Exports from the Southern region, for instance, are approximately four times as diversified as those from the Northern region. They are also twice as diversified as overall average Brazilian exports. Secondly, the graph reveals that both Southern and Southeastern regions also rejoiced from the sharpest increases in export diversification during the 2005 spike.

Figure 2

Evolution of the averaged region-by-region exports diversification

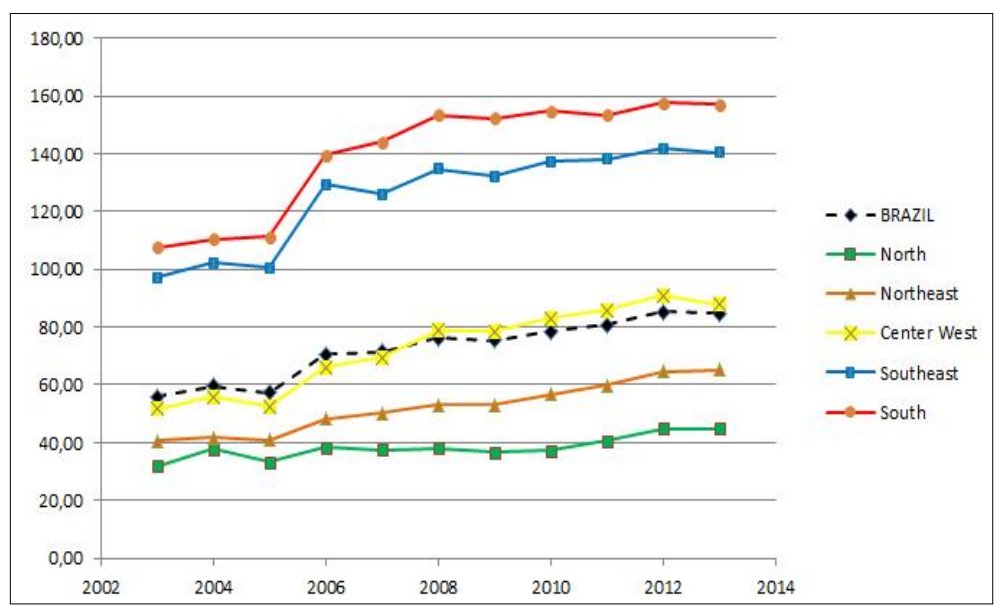

Source: Authors own elaboration based on Fapemig (2016).

The evolution of average Brazilian diversification was added as a means of comparison.

States in the Central-West region, on average, are shown to have the third-highest level of diversification. Overall, exports from these regions also diversified at a considerably faster rate than previously in 2005. Interestingly, after the spike, Central-West exports appear to have kept diversifying at a more stable and equally as large, if not larger, rate than exports from the

(1) The Industry Diversification Index was calculated by Fapemig (2016). 
Southern and Southeastern states. The same can be said about Northeastern exports, although they still remained the second least diversified in Brazil throughout the entire analyzed period. While South and Southeastern states appear to have contributed the most to increasing Brazilian diversification in 2005, from 2006 onward the Central-West and Northeastern states ultimately appear to have contributed equally as much, if not more, to further diversifying Brazilian exports. States from the Northern region maintained the least diversified export bundle throughout the entire analyzed period. This region, overall, was also the one that least diversified during and after the spike.

Figures 3A - 3C provide an overview of the structure of Brazilian exports in 2005, 2010 and 2015. It appears that the structure of Brazilian exports underwent considerable changes during this period. Compared to 1962, when half of Brazilian exports were made up of coffee, including green coffee, roasted coffee, and coffee substitutes (Felipe; Hidalgo, 2015), Brazilian exports became more diversified in terms of individual goods and individual goods categories' share of the country's total exports.

\section{Figure 3}

Gross export portfolio development in Brazil, by sector ${ }^{2}$

3A: Gross export portfolio, Brazil 2005

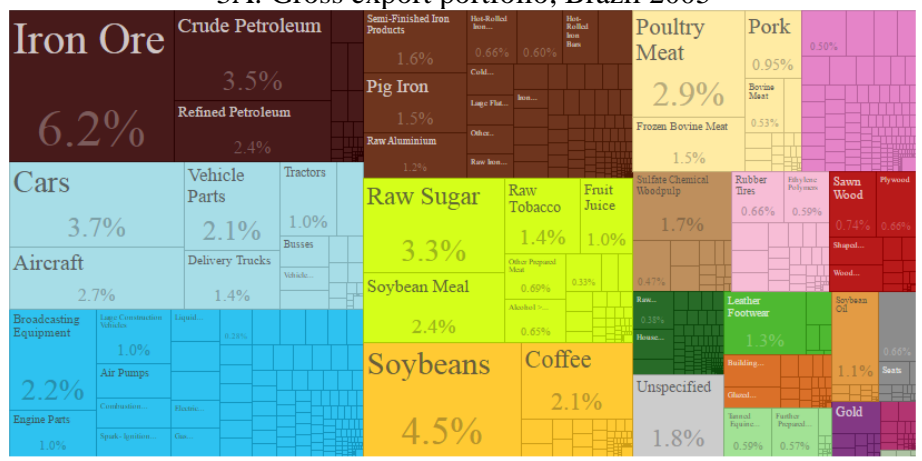

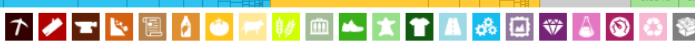

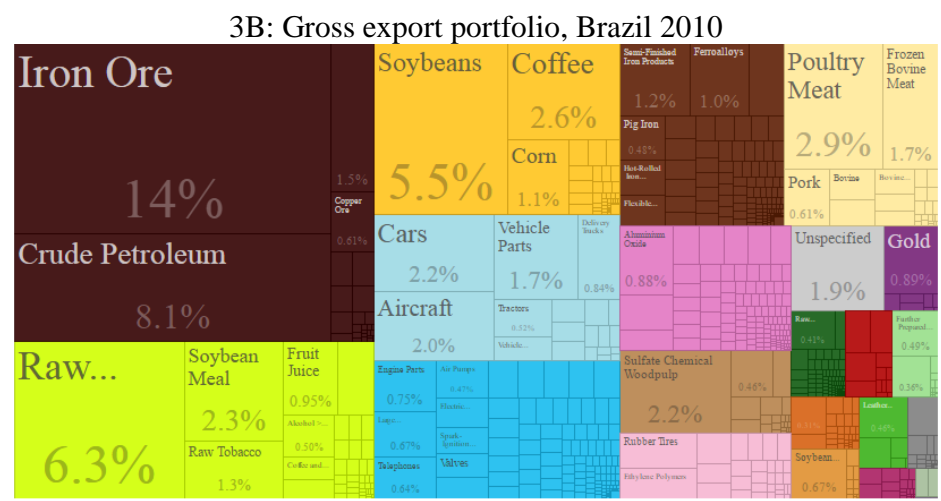

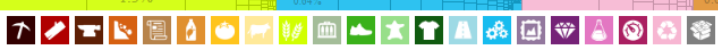

(2) For more details on the sectors analyzed in this paper, see Appendix 1. 


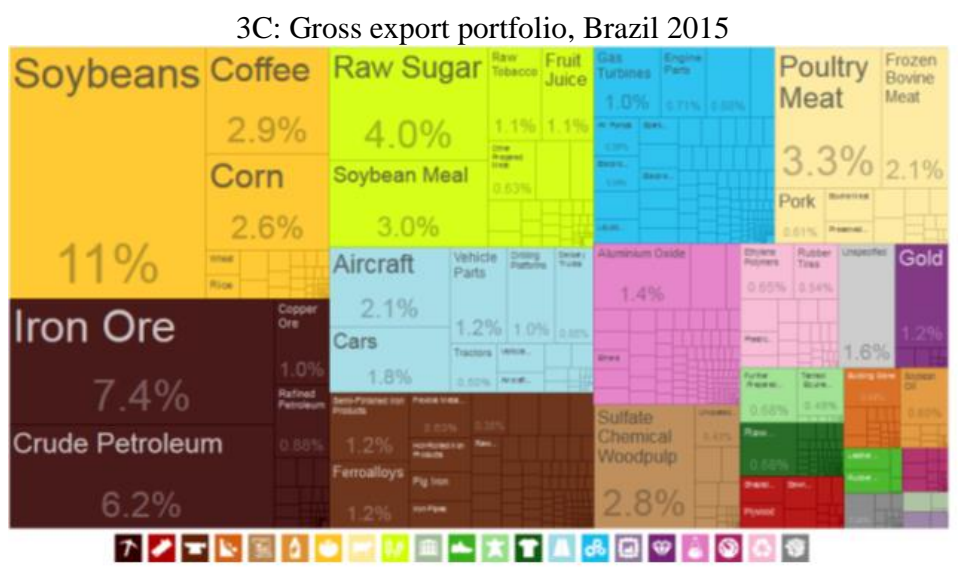

Source: Fapemig (2016).

Since 2005, the exports with the largest share of total exports have tended to grow, and are largely composed of commodities. On the other hand, the share of the most exported secondary goods has decreased since 2005 . This is a path that competing economies that have been successfully diversifying in the last couple of years, such as China, appear to have been careful to avoid. Overall, the Brazilian diversification performance since the beginning of the twenty-first century appears to be declining, or at the very least to be ambiguous. The country's export structure also underwent considerable changes during that period. This, and Brazil's difficulty in introducing new long-lived complex goods to its export bundle suggest that Brazilian export diversification during that period ought to be further analyzed.

In contrast to 2005 however, Brazilian exports in 2010 and 2015 appear to have, if anything, grown slightly more concentrated. Since 2010, exports of the most exported goods and of goods that are part of the same product category made up a larger share of total exports. Moreover, it is also worth noting that relative to 2005, the share of exported secondary goods, seems to have kept declining since 2010. This is relevant given that as discussed in the literature review, secondary products carry more potential to foster diversification than primary goods.

First, Brazil might have faced difficulties in creating the context and accumulating the capabilities necessary to engage in further diversification, especially towards more complex goods. Arnold et al. (2015) suggest that education for instance, which is commonly regarded as a pillar of human capital accumulation, is still lagging behind in Brazil, affecting the evolution of the Brazilian labor force productivity.

The low performance in increasing productivity could also reflect a failure to accumulate high-tech physical capital. Cirera, Marin, and Markwald (2012) suggest that the low survival rate of Brazilian exports in more complex goods between 2002 and 2008, was likely due to the fact that Brazil is thus lagging behind in terms of its capacity to put quality products in competitive and demanding markets. This trend does not seem to have improved in the most recent years. Arnold et al. (2015) report that since 2013, Brazilian real industrial 
output has kept decreasing. In addition to low educational attainment, they suggest that potential reasons for this include poor infrastructure, poorly designed policies that do not promote innovation and competition and difficult access to credit.

A second possible trigger to increasing export concentration between 2005 and 2015 is 'overly' successful cost and demand discoveries. For example, Hausman et al. (2014) affirm that the noticeable increase in Brazilian soy exports, particularly the increase in its share of worldwide exported soybeans reflects Brazil's recent revealed comparative advantage in soy. Higher soy exports for instance could showcase Brazils' export flexibility, and its capacity to adapt to an increasingly dynamic global demand market. This would suggest that cost and demand discoveries do not necessarily lead to further diversification. Moreover, it also suggests that international forces are also influential determinants of Brazilian export diversification.

A third plausible explanation for a higher concentration in specific products could be a deliberate attempt to engage in diversifying the Brazilian economy via vertical product quality diversification within those sectors. This could also explain higher productivity increases in the agricultural sector, but more importantly, it could mean that Brazilian diversification between 2005 and 2015 was again not as bad as previously observed.

Similarly, the diversification pattern observed from 1964 to 2015 did not account for the evolution of Brazilian exported services. The World Trade Organization (2015), however, reports that in 2014 Brazil ranked $34^{\text {th }}$ for the volume of exported commercial services worldwide. While this ranking does not provide information on the level of diversification of Brazilian commercial services exports, it still shows Brazil as the largest exporter of services in Latin America. More generally, Mattoo (2009) finds that Brazil, together with China and India, succeeded in fostering a remarkably large and fast increase of exported business services throughout the 1990s and the early 2000s.

\section{Econometrics specification}

\subsection{Dynamic panel analysis}

To identify determinants of Brazilian diversification, a Dynamic Panel Data analysis in first differences is utilized to account for unobserved heterogeneity arising from timeinvariant state-specific effects, and for time-related variations. Dynamic panel data differs from common panel data analysis with the inclusion of a lag of the dependent variable as an explanatory variable.

More recent econometric studies have favored the use of Arrellano and Bond's (1991) First Difference Generalized Method of Moments (FD-GMM) for dynamic panel data estimation. As suggested in Bon, Hoeffler, and Temple (2001), first differences are utilized to limit biases in the estimates arising from possible time-invariant omitted variables. Overall, estimators obtained via GMM have been subject to lower bias in the presence of endogeneity 
- which could arise for instance from possible omitted explanatory variables, measurement errors and simultaneity.

First consider the dynamic fixed effects model:

$y_{i t}=\gamma y_{i, t-1}+x_{i, t}^{\prime} \beta+\eta_{i}+\epsilon_{i, t} ;|\gamma|<1, i=1, \ldots, N$ and $t=2, \ldots, T$

$\in\left[\eta_{i}\right]=\in\left[\epsilon_{i, t}\right]=\in\left[\eta_{i} \epsilon_{i, t}\right]=0$

where $y_{i t}$ is the Economic Diversification Index for Brazilian states $i$ at year $t$, is a $x_{i, t}$ is a $(k-1) \times 1$ vector of exogenous regressors and $\epsilon_{i, t} \sim N\left(0, \sigma_{\epsilon}^{2}\right)$ is a random disturbance. Also, we assume that the residual $\epsilon_{i, t}$ is not correlated over time,

$\in\left[\epsilon_{i, t} \epsilon_{i, s}\right]=0 ;$ for $i=1, \ldots, N$ and $s \neq t$

and the initial condition, $y_{i, 1}$ is like,

$\in\left[y_{i, 1} \epsilon_{i, t}\right]=0 ;$ for $i=1, \ldots, N$ and $t=3, \ldots, T$

In this type of model, the ordinary least squares (OLS) presents biased estimators because of the correlation between $y_{i, t-1}$ and $\epsilon_{i, t}$. From the equations (1) to (4), Arellano and Bond (1991) suggested the use of lagged variables at least for two periods, as an instrument for the equation (1) in First Difference. For a small sample with T periods, there are 0.5(T1) $(T-2)$ sufficient moment conditions to identify and estimate the parameter $\gamma$.

However, for small data panel samples, Blundell and Bond (1998) show that FD-GMM presents weak properties for bias and imprecise estimates because of the lack of correlation between the instruments suggested by Arellano and Bond (1991) and the independent variable. Using Monte Carlos simulation, Blundell and Bond (1998) find the poor performance of the FD-GMM estimator at high values of $\gamma$. In that sense, Blundell and Bond (1998) propose the SYS-GMM which provides, based on Monte Carlo simulation, more efficient and robust estimators and good finite sample properties. Therefore, in this paper we use the SYS-GMM approach to estimate and analyze the determinants of economic diversification in the Brazilian states, even though the results for FD-GMM will be reported.

To verify whether or not there is still a bias in parameter $\gamma$, a commonly used method consists of comparing the given estimate with those obtained via the Ordinary Least Squares (OLS) and Within Group (WG) estimation methods. It can be assumed that the parameter obtained via the SYS-GMM is consistent and does not suffer from bias if it lies in between, and not close to those obtained via OLS and WG.

Based on the observation that estimators could become inconsistent in the presence of serial correlation in the error terms, Arellano and Bond (1991) suggest that a method to test the validity of the instruments and of the model overall is the Sargan test of over-identifying restrictions. The instruments and the model will be valid if the null hypothesis on the tests cannot be rejected. Finally, the Arellano and Bond test for first and second-order autocorrelation in the residuals, $\mathrm{AR}(1)$ and $\mathrm{AR}(2)$, will also be reported for both the FD-GMM 
and the SYS-GMM specifications, where the null hypothesis for the test is no autocorrelation in the residuals. If both the FD-GMM and SYS-GMM perform equally under the previous tests, the AR tests will provide further insights into determining the best specification.

\subsection{Variables description}

The data set utilized for the study comprises a total of 297 observations. No missing observations were recorded for any of the 27 states. Table 1 provides a description of the variables considered for the empirical model. The variables were chosen based on the literature and on data availability.

Table 1

Description of the variables used in the models

\begin{tabular}{|c|c|c|}
\hline Variables & Description & Source \\
\hline \multicolumn{3}{|l|}{ Dependent Variable } \\
\hline Diversification Index & $\begin{array}{c}\text { Industry Diversity Index as described in } \\
\text { Hausman (2009). The index includes the } \\
\text { number of unique 6-digit CNAE } \\
\text { industries that are present for a given } \\
\text { variable. }\end{array}$ & DataViva/FAPEMIG \\
\hline \multicolumn{3}{|l|}{$\begin{array}{l}\text { Independent } \\
\text { Variables }\end{array}$} \\
\hline $\begin{array}{l}\text { Lagged } \\
\text { Diversification }\end{array}$ & One year lagged dependent variable. & DataViVa/FAPEMIG \\
\hline Education & $\begin{array}{c}\text { Average Years of Schooling - People } \\
\text { who are } 25 \text { years old or more. }\end{array}$ & IPEADATA \\
\hline Population Density & $\begin{array}{c}\text { People per squared km based on our own } \\
\text { calculation. }\end{array}$ & $\begin{array}{l}\text { IBGE - Instituto Brasileiro de Geografia } \\
\text { e Estatística }\end{array}$ \\
\hline Patents per Capita & Yearly patents per capita (units). & $\begin{array}{l}\text { Instituto Nacional de Propriedade } \\
\text { Industrial }\end{array}$ \\
\hline Roads & Percentage of roads in good condition. & Confederação Nacional do Transporte \\
\hline Agriculture & $\begin{array}{l}\text { Share of agricultural land as a percentage } \\
\text { of total land. }\end{array}$ & IBGE \\
\hline Credit & $\begin{array}{c}\text { Credit supply by public and private banks } \\
\text { (RS). }\end{array}$ & Banco Central do Brasil \\
\hline Public Investment & Public investment $(\mathrm{R} \$)$ & Controladoria Geral da União \\
\hline
\end{tabular}

Source: Author's elaboration.

As discussed in the literature review, higher export diversification levels in the past should facilitate future diversification. Export diversification can foster the accumulation of quality and varied capabilities, the production of new complementary inputs, demand 
discoveries, gains in knowledge from foreign markets, inter-sectoral spillovers, and both intra and inter-sectorial productivity. The parameter of the lagged dependent variable is expected to be positive.

Education was included as a variable to proxy for human capital. Higher levels of education are expected to foster the development of a skilled labor force, which in turn fosters both successful exports and diversification. The parameter of the variable is expected to be positive.

Population Density was added based on urban economics literature to be associated with increases in productivity and economic growth. The explanations include higher face-toface interaction, and facilitated information and idea transmission, which both induce learning, knowledge and motivational spillovers, and attract citizens with a greater variety of skills from artists to bankers. Population Density is expected to have a positive parameter.

As discussed in the literature review, commodities, such as agricultural goods, have lower diversification potential, and possibly decreased future diversification. The variable Agriculture was added to account for possible negative spillovers of commodity production on diversification. The sign of the variable's parameter is expected to be negative.

The variable Patents per Capita was added as a proxy for both the number of innovations and for the strength of the Brazilian intellectual property right system and institutions. As pointed out by Cirera, Marin and Markwald (2012), innovations reflect the productivity of countries' accumulated capabilities, facilitating new export discoveries and promoting higher competitiveness in international markets. Intellectual property rights enable firms to feel more secure about returns on investments in research and development, especially in risky innovating areas. The parameter of Patents per Capita is expected to be positive.

The parameters of the variables Credit and Public Investment are both expected to be positive. The reason for this is that both variables represent a higher likeliness of investments in physical and human capital. Higher government spending can increase physical and human capital accumulation via investments in schools, research and infrastructure. Similarly, higher amounts of credit can reflect better access to credit, and thus the functioning of the financial sector, which decreased investment uncertainties.

The variable Roads was added as a proxy for quality public investments and availability of quality infrastructure. Moreover, good transport systems might also increase productivity by facilitating the acquisition of production inputs. The variable is thus expected to have a positive parameter.

\section{Results and discussion}

The regression output is presented in Table 2. Ultimately, the model was run under two stages and corrected for heteroskedasticity. The two stages of estimators tend to be more efficient asymptotically. The estimator of the lagged dependent variable found via two steps 
SYS-GMM lies in between those found via OLS and WG. No bias can thus be assumed. Moreover, the null of the Sargan test cannot be rejected. Both the instruments and models are thus assumed to be valid. The Arellano and Bond test for first and second-order autocorrelation in the residuals are also reported for the SYS-GMM specification. The null hypothesis of no autocorrelation fails to be rejected for second-order serial autocorrelation. The analysis of the regression results will thus be focused on the results from the S-GMM specification.

Table 2

Estimation results: economic diversification in the Brazilian states, 2003-2013

\begin{tabular}{lcccc}
\hline \multirow{2}{*}{ Variable/Method } & \multicolumn{4}{c}{ Dependent Variable: Diversification } \\
\cline { 2 - 5 } & OLS (I) & WG (II) & FD-GMM (III) & SYS-GMM (IV) \\
\hline Lagged & $0.7673^{* * *}$ & $0.2038^{* * *}$ & $0.4489^{* * *}$ & $0.6296^{* * *}$ \\
Diversification & $(0.0313)$ & $(0.03937)$ & $(0.0481)$ & $(0.0699)$ \\
\hline \multirow{2}{*}{ Education } & $2.1479^{* * *}$ & $13.0318^{* * *}$ & $7.3138^{* * *}$ & $2.9130^{*}$ \\
\hline \multirow{2}{*}{ Population Density } & $(0.8176)$ & $(1.3328)$ & $(1.6703)$ & $(1.6299)$ \\
\hline \multirow{2}{*}{ Patents Per Capita } & $-0.0251^{* * *}$ & $0.1389^{* *}$ & 0.0602 & 0.0520 \\
\hline \multirow{2}{*}{ Roads } & $(0.0095)$ & $(0.0827)$ & $(0.1628)$ & $(0.1044)$ \\
\hline \multirow{2}{*}{ Agriculture } & $18.7724^{* * *}$ & 9.1409 & 1.0371 & $23.8798^{* * *}$ \\
\hline \multirow{2}{*}{ Credit } & $(3.4622)$ & $(8.6551)$ & $(5.0276)$ & $(7.2734)$ \\
\hline \multirow{2}{*}{ Public Investments } & $0.28121^{* * *}$ & $0.3470^{* * *}$ & 0.1065 & 0.1642 \\
& $(0.0999)$ & $(0.1119)$ & $(0.0664)$ & $(0.1507)$ \\
\hline \multirow{2}{*}{ cons } & $-0.0317^{* * *}$ & $-0.5255^{* * *}$ & -0.1002 & -0.0067 \\
& $(0.0143)$ & $(0.1608)$ & $(0.0998)$ & $(0.0818)$ \\
\hline Observations & -0.000033 & 0.0010 & $0.0018^{* *}$ & $0.0019^{*}$ \\
\hline Sargan Test & $(0.0006)$ & $(0.0007)$ & $(0.0009)$ & $(0.0011)$ \\
AR(1) & 0.1433 & 0.1327 & $0.2582^{* * *}$ & $0.2189^{* *}$ \\
AR(2) & $(0.1201)$ & $(0.12345)$ & $(0.0595)$ & $(0.0707)$ \\
\hline Sourc: Author's & -3.3747 & -23.9632 & -13.9102 & -7.0800 \\
& $(5.0411)$ & $(9.5145)$ & $(8.6598)$ & $(8.3743)$ \\
\hline
\end{tabular}

Source: Author's elaboration.

The number of observations included by each method of estimation is reported in italics under the method name. The values for credits and public investments were scale divided by 1000 . Standard errors are reported in parenthesis. ${ }^{* * *}$ estimate significant for $\mathrm{p}<0.01,{ }^{* *}$ significant for $\mathrm{p}<0.05$, significant ${ }^{*} \mathrm{p}<0.10$.

The significant and positive coefficient of the lagged dependent variable implies that in the analyzed period, holding all else constant, on average higher levels of diversification in a state in the previous year fostered diversification in that same state in the following year. This shows that Brazilian states with a diversified productive structure in the previous year could maintain the same status during the following year. This result emphasizes the importance of considering capabilities that creates the condition to a more diversified economy over time. In 
this sense, as indicated by Agosin (2007) and Hausmann and Rodrick (2003), diversification is positively related to economic growth, and it may create a virtuous cycle where diversified economies tend to raise the local income level, in addition to stimulating future successful diversification.

The average years of schooling of citizens were found to be both statistically and economically significant. This result thus supports the importance of the creation of human capital via academic training in fostering export diversification.

The number of patents per capita secured in a given year was found to be a strong predictor of export diversification, both statistically and economically speaking. According to Breschi (1998), patents per capita would be good indicators of regional technological performance, allowing the investigation of the connection between the local innovation process and development economics. The process of innovation requires incentives to accumulate capabilities in a place where it is possible to create spillovers and strengthen the productive structure of a region's economy.

Finally, credits from private and public banks and public investments are both positive and statistically significant to economic diversification in Brazil. One could nonetheless question whether public and private banks that awarded credits have different impacts on diversification. In addition, regarding public investments, it is worth noting that the percentage of high-quality roads present in given states was not found to be a significant determinant of diversification. This would therefore suggest that different types of investments have had an unequal impact on export diversification in Brazil during the analyzed period.

These results show that the diversification process does not occur randomly and has predictable elements that can facilitate decision-making. Understanding which factors have an impact on economic diversification is an important step for the process of growth and development.

\section{Conclusion}

This paper has outlined the main arguments suggesting that diversifying export bundles, rather than specializing in them, leads to higher and more sustained growth and convergence potential for Brazil. In contrast to specialization, diversification via a portfolio effect provides a safety net against growth-hampering volatilities. Diversification is also argued to allow for more dynamic benefits that foster growth than specialization, such as promoting cost and demand discoveries, and generating a faster and more varied accumulation of capabilities, and other production inputs. Diversification is argued to lead to more intra and inter-sectorial spillovers and growth.

The literature on successful diversification, however, suggests that not all diversification paths carry equal economic growth and diversification potential. First, a great deal of the literature supports the idea that introducing more complex goods into DMCs export 
bundles fosters a faster accumulation of capabilities, and has more potential to further economic growth and diversification. On the other hand, some authors suggest that diversification of primary goods, not only has low diversification potential, but can also enable exports to diversify towards other sectors. Secondly, amongst other determinants of diversification, capability accumulations are commonly highlighted, especially of skilled and varied human capital.

Regarding the diversification of Brazilian exported products between 2003 and 2013, the following conclusions were reached. First, Brazilian exports were indeed found to have grown more diversified throughout the analyzed period, and neither long-term nor substantial concentration trends were observed. In fact, although Brazilian exports did become more concentrated between 2008 and 2009, they experienced a relatively important and stable period of diversification from 2009 to 2012. On the other hand, exports decreased, after 2010, between 2012 and 2013, and grew in concentration up until 2015. The empirical results revealed that Brazilian exports had decreased, momentarily, in two instances before 2012. This reinforces the fact that it cannot be assumed that the concentration pattern observed in 2012, and perhaps in the following couple of years, will continue in the long-term.

Secondly, the study further confirmed that export diversification across Brazilian regions varies considerably. It revealed that this variation was also important across states, and even across states belonging to the same region. The large North-South diversification gap was observed in the case study results. Moreover, South and Southeastern states were found to have clearly diversified the most during the 2005 spike, and therefore were those that most contributed to diversifying Brazilian exports during that period. While almost all states were found to have rejoiced from a sharper diversification rate during 2005, they differed greatly with regards to the total amount of diversification they managed to secure. As a result, the spike considerably accentuated the variation in export diversification across regions and states. It was also possible to demonstrate that after 2006 the highest diversification gains actually occurred in the Central-West and Northeastern states. While these states did not experience a diversification spike as large as that in the South and Southeastern states, they indeed experienced a more steady and sharp increase in diversification from 2006 onwards.

Thirdly, the regression results suggested that previous export diversification, average years of schooling of the population aged 25 and older, population density, the number of credits given by private and public banks, and public investments were all positive and significant determinants of Brazilian diversification during the studied period.

Finally, this research faced limitations, some of which could also be interesting starting points for future works. The paper mainly accounted for the horizontal diversification of Brazilian exported products. The analysis of Brazilian export vertical-quality diversification, and of the evolution of its services industry could notably provide a more complete, and perhaps more accurate, understanding of the country's overall exports diversification. With regard to the determinants of Brazilian diversification, a more complete analysis should 
Heder Carlos de Oliveira, Elodie Jegu, Venussia Eliane Santos

consider additional factors such as diversification scope and foreign demand. Lastly, additional research, specifically studying the dynamics between higher export diversification and economic growth within Brazil, could further legitimize and motivate future studies on the evolution of Brazilian export diversification.

\section{References}

AGOSIN, M. Export diversification and growth in emerging economies. Cepal Review, p. 115-131, 2000.

AHN, S.; SCHMIDT, P. Efficient estimation of dynamic panel data models: alternative assumptions and simplified estimation. Journal of Econometrics, v. 76, n. 1-2, p. 309-332, 1993.

ALINK, M.; KOMMER, V. Chapter 1: Taxation. In: HANDBOOK on tax administration. $8^{\text {th }}$ ed. Amsterdam: IBFD, 2011. p. 1-58.

AL-MARHUBI, F. Export diversification and growth: an empirical investigation. Applied Economics Letters, v. 7, p. 559-562, 2000.

ADITYA, A.; ACHARYYA, R. Export diversification, composition, and economic growth: evidence from cross-country analysis. The Journal of International Trade \& Economic Development, v. 22, n. 7, p. 959-992, 2013.

ARELLANO, M.; BOVER, O. Another look at the instrumental variable estimation of errorcomponents models. Journal of Econometrics, v. 68, n. 1, p. 29-51, 1995.

ARNOLD, J.; MURAKAMI, Y.; BUENO, M.; ARAÚJO, S.; BEYNET, P. OECD Economic Surveys: Brazil. Paris: OECD Publishing, 2015. p. 6-42.

BAFFLES, J.; LEWIN, B.; VARANGIS, P. Chapter 16 - Coffee: market setting and policies. In: ATAMAN, M.; BEGHIN, J.C. Global agricultural trade and developing countries. Washington D.C.: World Bank, 2005. p. 297-309.

BLUNDELL, R.; BOND, S. Initial conditions and moment restrictions in dynamic panel data models. Journal of Econometrics, v. 87, n. 1, p. 115-143, 1998.

BON, S.; HOEFFLER, A.; TEMPLE, J. GMM estimation of empirical growth models. London: Center for Economic Policy Research, 2011. p. 1-25. (Discussion Paper, n. 3048).

CHANDRA, V.; BOCCARDO J.; OSORIO, I. Export diversification and competitiveness in developing countries. Washington, D.C.: World Bank, 2007.

CIRERA, X.; MARIN, A.; MARKWALD, R. Firm behaviour and the introduction of new exports: evidence from Brazil. IDS, 2012. p. 1-105. (Working Papers, n. 390).

COLLIER, P.; DOLLAR, D. Chapter1: The new wave of globalization and its economic effects. In COLLIER, P.; DOLLAR, D. Globalization, growth, and poverty: building an inclusive world economy. Washington DC: World Bank, 2002. p. 23-51. 
DA SILVA, N.; DA SILVA, G. Contribuição do setor madeireiro à balança comercial do estado de Roraima: contexto econômico e ambiental. Revista Acta Geográfica, n. 3, p. 85-91, 2008 .

DAWE, D. A new look at the effects of exports instability on investment and growth. World Development, v. 24, p. 1905-1914, 1996.

DEBCZUKY, R.; BERRETTONI, D. Explaining export diversification: an empirical analysis. CAF Research Program on Development Issues, p. 1-35, 2006.

ELHIRAIKA, A. B.; MBATE, M. M. Assessing the determinants of export diversification in Africa. Applied Econometrics and International Development, v. 14, n. 1, p. 147-160, 2014.

FAPEMIG. Plataforma de Dados Econômicos e Sociais do Brasil. 2016.

FELIPE, J. Modern industrial policy. In: JESUS, F. (Ed.). Development and modern industrial policy in practice. Cheltenham: Edward Elgar, 2015. p. 1-23.

GELB, A. Economic diversification in resource rich countries. Drawn from: Lecture At A High-Level Seminar On Natural Resources, Finance And Development: Confronting Old And New Challenges. Organized by the Central Bank of Algeria and IMF Institute in Algiers. 2010.

GNANGNON, K.; MOSER, C. Intellectual property rights protection and export diversification: the application of utility model laws. Geneva: World Trade Organization, 2014. p. 1-36. (Working Paper ERSD).

GROSSMAN, G.; HELPMAN, E. Innovation and growth in the global economy. Cambridge: MIT Press, 1992. p. 359.

GYLFASON, T.; HERBERTSSON, T. T.; ZOEGA, G. A mixed blessing: natural resources and economic growth. Macroeconomic Dynamics, v. 3, p. 204-225, 1999.

HAUSMANN, R.; RODRIK, D. Economic development as self-discovery. Journal of Development Economics, v. 72, n. 2, p. 603-633, 2003.

HECKSCHER, E. F. The effect of foreign trade on the distribution of income. (English translation of the original 1919 article in 1919, Ekonomisk Tidskrift). 1919.

HERZER, D.; FELICITAS NOWAK-LEHMANN, D. What does export diversification do for growth? An econometric analysis. Applied Economics, v. 38, n. 15, p. 1825-1838, 2006.

HUSTED, S.; MELVIN, M. Chapter 3: the classical model of international trade. In: INTERNATIONAL Economics. $8^{\text {th }}$ ed. Boston: Addison-Wesley, 2010. p. 54-67.

INMAN, P. Brazil's economy overtakes UK to become world's sixth largest. The Guardian. 2012. Retrieved from: https://www.theguardian.com/business/2012/mar/06/brazil-economyworlds-sixth-largest. 
Heder Carlos de Oliveira, Elodie Jegu, Venussia Eliane Santos

KAULICH, F. Diversification vs. specialization as alternative strategies for economic development: can we settle a debate by looking at the empirical evidence? Vienna: United Nations Industrial Development Organization, 2012. (Working Paper, n. 3).

KRUGMAN, P. R. Is free trade passé? The Journal of Economic Perspectives, v. 1, n. 2, p. 131-144, 1987.

KUME, L. Uma estimativa dos determinantes da taxa de criminalidade brasileira: uma aplicação em painel dinâmico. Presented at a meeting from the ANPEC. 2004.

KUZNETS, S. Economic growth of nations: total output and production structure. Cambridge, Mass.: Harvard University Press, 1971.

KUZNETS, S. Modern economic growth: findings and reflections. Prize Lecture, Nobelprize.org., 2014.

LALL, S. Skills, competitiveness and policy in developing countries. University of Oxford, Queen Elizabeth House, 2000. (Working Paper, QEHWPS46).

LEDERMAN, D.; MALONEY, W.F. Does what you export matter? In search of empirical guidance for industrial policies. Washington: The World Bank, 2012. p. 57-89.

LOAYZA, N.; RANCIÈRE, R.; SERVÉN, L.; VENTURA, J. Macroeconomic volatility and welfare in developing countries: an introduction. The World Bank Economic Review, v. 21, n. 3, p. 343-357, 2007.

LOBO, J.; BETTENCOURT, L.; STRUMSKY, D.; WEST, G. B. The economic productivity of urban areas: disentangling general scale effects from local exceptionality. Santa Fe: Santa Fe Institute, 2011. p. 1-20. (Working Paper SFA-2011-09-046).

LUCAS, R. On the mechanics of economic development. Journal of Monetary Economics, v. 22, n. 1, p. 3-42, 1988.

MARISCAL, R.; POWELL, A. Commodity price booms and breaks: detection, magnitude and implications for developing countries. Inter-American Development Bank, 2014. p. 1-42. (Working Paper, n. 444).

MATTOO, A. Exporting services. In: NEWFARMER, R.; SHAW, W.; WALKENHORST, P. Breaking into new markets: emerging lessons for export diversification. Washington D.C.: World Bank Publications, 2009. p. 161-181.

MEJÍA, J. F. Export diversification and economic growth: an analysis of Colombia's export competitiveness in the European Union's market. Berlin: Physica-Verlag, 2011. p. 9-11, p. 8083 .

MOBARAK, A. M. Democracy, volatility, and economic development. The Review of Economics and Statistics, v. 87, n. 2, p. 348-361, 2005. 
NEWFARMER, R.; WALKENHORST, P.; SHAW, W. Breaking into new markets: emerging lessons for export diversification. Washington D.C.: The World Bank, 2009. p. xi-xiv.

OHLIN, B. Interregional and international trade. 1933.

PERMAN, R.; MA, Y.; COMMON, M., MADDISON, D.; McGILVRAY, J. Chapter 10: Trade and the environment. In: NATURAL resource and environmental economics. $4^{\text {th }}$ ed. Harlow, Essex: Pearson Education, 2011. p. 342-347.

RAMEY, G.; RAMEY, V. A. Cross-country evidence on the link between volatility and growth. The American Economic Review, v. 85, n. 5, p. 1138-1151, 1995.

ROMER, P. Endogenous technological change. Journal of Political Economy, v. 98, n. 5, p. 71-102, 1990.

SACHS, J. D.; WARNER, A. M. Natural resources and economic development: the curse of natural resources. European Economic Review, v. 45, n. 4-6, p. 827-838, 2001.

TOYE, J. F. J.; TOYE, R. The origins and interpretation of the Prebisch-Singer Thesis. History of Political Economy, v. 35, n. 3, p. 437-467, 2003.

VETTAS, N. Investment dynamics in markets with endogenous demand. The Journal of Industrial Economics, v. 48, n. 2, p. 189-203, 2000.

VERHEIJ. T.; OLIVEIRA, H. C. Is economic complexity spatially dependent? A spatial analysis of interactions of economic complexity between municipalities in Brazil. International Conference on Economic Modeling (EcoMod2017). Ljubljana, Slovenia, 2017.

WORLD TRADE ORGANIZATION. International Trade Statistics. Geneva, WTO, 2016. p. 1-46. Retrieved from: https://www.wto.org/statisticshttps://www.wto.org/english/res_e/ statis_e/its2015_e/its2015_e.pdf. 